ність номінації тієї чи тієї ситуації, нанизування ситуацій у полісемантичній реченнєвій структурі, що й цілком відбиває сутність номінативно-екзистенційного простору реченнєвої структури.

За умови перевидання надзвичайно цікавого й важливого рецензованого дослідження можна побажати доповнити його термінологічним індексом та індексом цитованих та згадуваних авторів наукових праць і використаних джерел фактичного матеріалу.

Рецензована монографія М. Степаненка $є$ актуальна за проблематикою, викінчена за структурою, надзвичайно ємна за кількістю охопленого й належним чином проаналізованого фактичного матеріалу, рівнем теоретичного осмислення надзвичайно складної проблеми. Вихід у науковий простір такого рівня дослідження розширює загальне розуміння граматичного ладу сучасної української мови, закономірностей співвідносності в ії̈ системі субстанційних і предикатних величин, розуміння багатства й колоритності реченнєвих утворень ядрового й похідного характеру.

Анатолій Загнітко, Володимир Манакін

\title{
СХІДНОСТЕПОВІ УКРАЇНСЬКІ ГОВІРКИ НА МАПАХ
}

Рецензія на дослідження: Клименко Н.Б. Атлас побутової лексики (назви одягу) східностепових говірок Донеччини. Покровськ: ДВНЗ «ДонНТУ», 2020. $200 \mathrm{c}$.

DOI 10.31558/1815-3070.2020.40.1.18

УДК 811.161.2 (477.62)

У сучасному науковому лінгвістичному просторі укладання атласів та їх оприлюднення не належить до активно опрацьовуваних, хоча їх значущість важко переоцінити, оскільки вони не лише висвітлюють загальне тло поширення відповідних мовних явищ, а й подають їх якісний, функційний та кількісний виміри. Рецензований атлас свідчить про значний обсяг виконаної роботи, що охоплює не одне десятиліття. Більше того, аналізований атлас не міг постати без самовідданості його авторки лінгвістичній справі. Пригадуються численні розмови, круглі столи, дискусії щодо упорядкування величезного матеріалу з обстеження українських східностепових говірок. Н.Б. Клименко підтримала ідею та слала одним із найактивніших реалі заторів створення першої в слов'янському лінгвістичному світі хрестоматії українських східностепових говірок, що здобула високу оцінку 3-поміж авторитетних науковців, а також молодих дослідників діалектології, аспірантів і магістрантів. А згодом Н.Б. Клименко разом із іншими колегами ініціювала створення словника українських східностепових говірок Донеччини, перший випуск якого засвідчив прагнення подати цілісну лексичну картину цих. Роботу над наступними випусками словника українських східностепових говірок Донеччини на кафедрі української мови та прикладної лінгвістики Донецького національного університету, на жаль, перервали відомі 
події 2014 року, через які було втрачено значну частину фонду - картотеку, численні записи, паперові карти та багато іншого. Тому сформування цілісного атласу словника українських східностепових говірок Донеччини підтверджує тяглість діалектологічної традиції донецьких науковців і відображає високу відданість справі самої дослідниці Н.Б. Клименко.

Аналізований атлас побутової лексики (назви одягу) східностепових говірок Донеччини постає належним чином структурований, охоплюючи Передмову, в якій висвітлено загальне тло усіх наукових студіювань, що присвячені обстежуваному говірковому ландшафту. А також розгляд нинішнього районного адміністрування Донецької області, що уможливлює чітку картографічну локалізацію висвітлюваних лексем. Індекс обстежених населених пунктів Донецької області містить 110 населених пунктів, що рівномірно й достатньо охоплюють увесь простір Донеччини, що легко простежити на матеріалі алфавітного списку обстежених населених пунктів Донецької області.

Значущість обстежуваного простору можна вважати унікальним (подібно до Атласу М. Кушмет-Бадаммер), оскільки значна частина з них сьогодні не лише не доступна для аналізу, а й, певною мірою, втрачена, У цьому разі можна лише подякувати дослідниці за збереження матеріалу та належне його лінгвогеографічне опрацювання. Про грунтовність рецензованого атласу свідчить індекс картографованих лексем з опертям на відповідні карти атласу, реалізацією їх фонетичного портрету. Подібна репрезентація уможливлює встановлення функційного статусу певних ареалів тих чи тих лексем, визначення їхніх зв'язків і под. У наведеному Списку літературі повністю репрезентовані актуальні студіювання східностепових українських говірок Донеччини. Наявні тут також дві наукові праці Кушмет-Бодаммер М. С. (Діалектологічний портрет Донеччини: кінець 2014 р. (сільськогосподарська лексика). Тернопіль: Крок, 2017. 260 с.; Кушмет-Бодаммер М. С. Атлас сільськогосподарської лексики східностепових говірок Донеччини. Тернопіль: Крок, 2017. 204 с. : карти). Заявлені дослідження виконані під керівництвом Н.Б. Клименко.

Насамкінець потрібно наголосити на тому, що подібні дослідження завжди мають опертям численні студіювання відповідних наукових шкіл, наукових напрямів, а також відданість авторів чітко окресленим проблемам. Підтвердженням цьому є численні наукові статті, словники та інше Н.Б. Клименко, іiі організаційна робота, що була зорієнтована на проведення декількох всеукраїнських конкурсів студентських науково-дослідних робіт із діалектології.

Структура атласу побутової лексики (назви одягу) східностепових говірок Донеччини, цілком мотивована симетрія складників, їх змістове наповнення, достатня репрезентативність обстежуваного матеріалу підтверджують актуальність і значущість рецензованої праці, функційне навантаження якої в сучасному науковому просторі важко переоцінити. 